\title{
KEEFEKTIFAN MODEL EXAMPLES NON EXAMPLES TERHADAP HASIL BELAJAR MATERI PENGUKURAN KELAS III
}

\author{
Yogi Widya Kusuma ${ }^{1}$, Joko Sulianto ${ }^{2}$, Veryliana Purnamasari ${ }^{3}$ \\ 1,2,3 Jurusan PGSD FIP Universitas PGRI Semarang, Indonesia \\ e-mail: yogi.widyakusuma@gmail.com
}

\begin{abstract}
Abstrak
Model pembelajaran adalah kerangka konseptual/operasional yang melukiskan prosedur yang sistematis dalam mengorganisasikan pengalaman belajar untuk mencapai tujuan belajar tertentu dan berfungsi sebagai pedoman bagi para pengajar dalam merencanakan dan melaksanakan aktivitas belajar. Tujuan dari penelitian ini adalah untuk menguji Keefektifan Model Examples Non Examples Terhadap Hasil Belajar Siswa Materi Pengukuran. Dalam menggunakan model tersebut terdapat perubahan yang signifikan. Rumusan masalah pada permasalahan di atas adalah: "Apakah Model Examples Non Examples Efektif Terhadap Hasil Belajar Materi Pengukuran Siswa Kelas III SDN Sidokerto 03 Pati?". Penelitian yang digunakan adalah penelitian kuantitatif. Dalam Penelitian ini menggunakan dua variabel yaitu variabel bebas $(X)$ dan variabel terikat $(Y)$, dengan variabel bebas $(X)$ model pembelajaran Examples Non Examples. Sedangkan variabel terikatnya (Y) yaitu hasil belajar siswa. Populasi penelitian adalah seluruh siswa kelas III SD Negeri Sidokerto Pati dengan jumlah 30 siswa. Sampel yang diambil adalah 30 siswa kelas III dengan menggunakan Pre Eksperimental Designs bentuk One-Group PretestPosttest Design. Berdasarkan hasil analisis hipotesis nilai rata-rata hasil pretest siswa yang sebesar 57,17 dan rata-rata nilai hasil posttetst dengan menggunakan Model Examples Non Examples sebesar 79,83. Dari tabel uji t diperoleh , untuk , maka diperoleh dan . Karena yaitu maka ditolak. Dengan demikian terdapat keefektifan model Examples Non Examples terhadap hasil belajar materi pengukuran siswa Kelas III SDN Sidokerto 03 Pati dan Dari hasil nilai posttest kelas III menunjukan bahwa hasil belajar setelah mendapatkan perlakuan dengan menggunakan Model Examples Non Examples meningkat dibandingkan dengan sebelum mendapatkan perlakuan menggunakan Model Examples Non Examples.
\end{abstract}

Kata-kata kunci : Examples non Examples, hasil belajar

\begin{abstract}
The learning model is a conceptual / operational framework that describes a systematic procedure in organizing learning experiences to achieve certain learning goals and serves as a guide for teachers in planning and carrying out learning activities. The purpose of this study was to examine the effectiveness of Examples Non Examples of Models on Student Learning Outcomes in Measurement Materials. In using the model there were significant changes. The formulation of the problem in the problem above is: "Are Examples Non Examples Models Effective for Learning Outcomes in Measurement Material of Class III Students at SDN Sidokerto 03 Pati?". The research used is quantitative research. In this study using two variables, namely the independent variable $(\mathrm{X})$ and the dependent variable $(\mathrm{Y})$, with the independent variable $(X)$ learning model Examples Non Examples. While the dependent variable $(\mathrm{Y})$ is student learning outcomes. The study population was all third grade students of Sidokerto Pati Elementary School with a total of 30 students. The samples taken were 30 grade III students using Pre Experimental Designs in the form of One-Group Pretest-Posttest Design. Based on the results of the hypothesis analysis the average value of the students' pretest results was 57.17 and the average value of the posttest results using the Examples Non Examples Model was 79.83. From the test table t
\end{abstract}


obtained, for, then obtained and. Because that is why it is rejected. Thus there are effectiveness models Examples Non Examples on learning outcomes measurement material Class III students of SDN Sidokerto 03 Pati and from the results of class III posttest values show that learning outcomes after getting treatment using Examples Non Examples Model increases compared to before getting treatment using Non Examples Model Examples.

Key words: Examples non Examples, learning outcomes

\section{Pendahuluan}

Dengan kemajuan teknologi informasi dan komunikasi, saat ini di dalam dunia pendidikan memerlukan usaha yang optimal untuk dapat mengahasilkan peserta didik yaang berkualitas dengan dasar guru sebagai pembibingnya di sekolah guna dapat menghadapi di era global yang lebih maju dengan adanya teknologi dan informasi terutama di dalam bidang pendidikan. Untuk itu pendidik harus dapat menguasai, menerapkan dan mengembangan kemampuan mengajarnya dengan adanya teknologi yang telah ada. Dalam melaksanakan kegiatan belajar mengajar yang dilakukan di dalam kelas sering dijumpai masalah, antara lain cara mengajar pendidik yang kurang menarik, penggunaan media yang kurang tepat, serta pendidik yang kurang terbiasa mengembangkan media yang sudah ada sehingga pembelajaran di kelas kurang menarik dan bervariasi maka dari itu peserta didik kurang tertarik dalam mengikuti pembelajaran di kelas.

Matematika terdapat materi tentang alat ukur yang materinya memuat prinsip mengamati, mencermati, dan menghitung sehingga memerlukan pemahaman yang lebih. Hal tersebut dapat membuat peserta didik bosan dan jenuh dalam mengikuti proses pembelajaran di dalam kelas. Dengan demikian, pendidik harus dapat membuat suasana bosan dan jenuh menjadi proses pembelajaran yang menarik dan menyenagkan sehingga guru dapat memanfaatkan media, model, ataupun metode yang sudah ada dan mengembangkannya meskipun hanya sederhana.

Pembelajaran matematika sebagai ilmu universal, memiliki peran penting mendasari perkembangan teknologi modern dalam memajukan pola pikir manusia. Matematika adalah pelajaran yang dibutuhkan oleh peserta didik dalam kehidupan sehari-hari (Permendikbud Nomor 81 A). Pembelajaran matematika di Sekolah Dasar (SD) merupakan sarana berpikir ilmu dasar yang harus dimiliki peserta didik dalam menyelesaikan masalah yang berkaitan dengan kehidupan sehari-hari. Pendidikan dimasa sekarang yaitu memberi bekal peserta didik untuk belajar secara efektif dalam zaman teknologi. Pembelajaran di SD diharapkan dapat memberikan pembelajaran yang efektif dan efisien sesuai kurikulum dan pola pikir peserta didik untuk menyelesaikan masalah matematika berkaitan dengan kehidupan sehari-hari (Wahyudi dan Kriswandani, 2013).

Menurut Joyce dalam bukunya Trianto (2007: 5) model pembelajaran adalah suatu perencanaan atau suatu pola yang digunakan sebagai pedoman dalam merencanakan pembelajaran di kelas atau pembelajaran dalam tutorial dan untuk menentukan perangkatperangkat pembelajaran termasuk di dalamnya buku-buku, film, komputer, kurikulum, dan lainlain. Model pembelajaran mengarahkan pendidik dalam mendesain pembelajaran untuk membantu peserta didik sedemikian rupa sehingga tujuan pembelajaran tercapai. Examples Non-Examples merupakan strategi pembelajaran yang menggunakan gambar sebagai media untuk menyampaikan materi pelajaran (Huda, 2013: 234).

Menurut Utami dkk (2015: 178) menyatakan bahwa model pembelajaran examples non-examples memiliki karakteristik sebagai berikut: Proses pembelajaran mengikutsertakan proses mental peserta didik secara maksimal, tidak hanya menuntut peserta didik sekedar mencatat, mendengar, akan tetapi menghendaki aktivitas peserta didik untuk berfikir, dalam proses pembelajaran meciptakan kondisi dialogis dan proses tanya jawab terus menerus yang diarahkan untuk memperbaiki dan meningkatkan kemampuan berfikir peserta didik. 
Selain kendala yang dialami oleh pendidik ada pula kendala dan permasalahan yang dialami oleh peserta didik di dalam mengikuti pelajaran yang disampaikan oleh pendidik. Siswa kurang aktif dalam kegiatan pembelajaran dan terkadang penjelasan guru terlalu cepat sehingga siswa kurang memahami materi yang diberikan. Pembelajaran yang dilakukan kurang berpusat pada siswa dan metode pembelajaran yang digunakan oleh pendidik masih belum maksimal diterapkan pada pembelajaran matematika sehingga peserta didik yang belum paham. Ada beberapa siswa yang kurang bergairah dan kurang aktif dalam pembelajaran. Hasil belajar siswa masih dibawah KKM yang ditetapkan yaitu 70 . Dalam pembelajaran yang membosankan, terkadang peserta didik merasa kurang bersemangat dalam mengikuti pembelajaran yang dilaksanakan.

Hal ini dibuktikan dengan hasil Ulangan Kenaikan Kelas (UKK) matematika siswa kelas III SDN Sidokerto 03 Pati 2017 masih banyak siswa yang mendapatkan nilai di bawah KKM atau nilai kurang dari 70 . Dari 30 siswa terdapat 18 siswa yang mendapat hasil ulangan di bawah 70 .

Dengan ini peneliti akan memberikan solusi dengan akan melakukan penelitian untuk dapat meningkatkan hasil belajar siswa meningkat dalam pelajaran matematika pada materi pengukuran. Peneliti mengajukan penelitian dengan judul "Keefektifan Model Examples Non Examples Terhadap Hasil Belajar Materi Pengukuran Siswa Kelas III SDN Sidokerto 03 Pati“.

Adapun tujuan dari penelitian ini bertujuan untuk mengetahui Keefektifan Model Examples Non Examples Terhadap Hasil Belajar Materi Pengukuran Siswa Kelas III SDN Sidokerto 03 Pati.

Hasil dari penelitian ini diharapkan dapat digunakan sebagai bahan informasi ilmiah untuk menambah wawasan serta pengetahuan bagi guru dalam memilih dan menggunakan model pembelajaran yang akan digunakan dalam proses belajar mengajar dalam kelas. Penelitian ini dapat berguna sebagai bentuk sumbangan pemikiran agar dapat meningkatkan kualitas pembelajaran di SDN Sidokerto 03 Pati terutama pada kelas III.

\section{Metode}

Metode yang akan digunakan dalam penelitian ini adalah metode eksperimen. Metode eksperimen dapat diartikan sebagai metode penelitian yang digunakan untuk mencari pengaruh perlakuan tertentu terhadap yang lain dalam kondisi yang terkendalikan (Sugiyono, 2016:72). Penerapan dari metode penelitian ini akan digunakan untuk mencari Keefektifan Model Examples Non Examples Terhadap Hasil Belajar Materi Pengukuran Siswa Kelas III SDN Sidokerto 03 Pati.

Desain penelitian dirancang untuk menjawab pertanyaan atau mengetes hipotesis penelitian. Penelitian ini menggunakan Pre Eksperimental Designs bentuk One-Group Pretest-Posttest Design. Pada desain ini terdapat pretest, sebelum diberi perlakuan. Dengan demikian hasil perlakuan dapat diketahui lebih akurat, karena dapat membandingkan dengan keadaan sebelum diberi perlakuan (Sugiyono,2014:74).

Prosedur peneliti yang pertama adalah ke lapangan. Peneliti sebelumnya sudah melakukan observasi ke lapangan sebagai studi pendahuluan. Jenis tes dalam penelitian ini yaitu pretest dan Posttest dengan bentuk pilihan ganda untuk mengukur pemahaman siswa terhadap mata pelajaran matematika dalam pemebalajaran dengan menggunakan model pembelajaran Examples Non Examples.

Uji coba instrumen dilakukan dengan melakukan uji validitas, uji reliabilitas, analisis daya pembeda dan tingkat kesukaran.

Uji normalitas pada awal yaitu pada hasil perolehan data dari soal tes yang diperoleh sebelum melaksanakan proses pembelajaran dengan menggunakan model pembelajaran examples non examples. Uji ini berfungsi untuk mengetahui apakah data - data tersebut secara normal atau tidak. Untuk mengetahui suatu sampel dari populasi yang ada bisa digunakan uji liliefors. Hipotesis statistika dalam uji normalitas adalah sebagai berikut:

Ho : sampel berasal dari data berdistribusi normal 


\section{Hasil dan Pembahasan}

Berdasarkan Penelitian ini dilaksanakan untuk mengetahui Keefektifan Model Examples Non Examples Efektif Terhadap Hasil Belajar Materi Pengukuran Siswa Kelas III SDN Sidokerto 03 Pati.

Sebelum melaksanakan penelitian, peneliti melaksanakan studi pendahuluan untuk mengetahui permasalahan yang ada di kelas dan diperoleh informasi Siswa kurang aktif dalam kegiatan pembelajaran dan kadang-kadang penjelasan guru terlalu cepat sehingga siswa kurang memahami materi yang diberikan. Pembelajaran yang dilakukan kurang berpusat pada siswa dan metode pembelajaran yang digunakan oleh pendidik masih belum maksimal diterapkan pada pembelajaran matematika sehingga peserta didik yanng belum paham. Ada beberapa siswa yang kurang bergairah dan kurang aktif dalam pembelajaran. Hasil belajar siswa masih dibawah KKM yang ditetapkan yaitu 70. Pembelajaran yang membosankan, sehingga peserta didik merasa kurang bersemangat dalam mengikuti pembelajaran yang dilaksanakan. Oleh sebab itu perlu adanya upaya untuk menarik minat siswa dalam belajar yaitu dengan menggunakan model pembelajaran yang kreatif dengan menerapkan Model Examples Non Examples supaya pembelajaran lebih menarik dan membuat siswa lebih aktif dalam proses pembelajaran.

Peneliti mempersiapkan rencana pelaksanaan pembelajaran yang akan dilaksanakan dalam 3 kali pertemuan. Sebelum menerapkan pembelajaran menggunakan Model Examples Non Examples peneliti terlebih dahulu membagikan soal pilihan ganda sebagai pretest kepada siswa untuk dikerjakan.

Berdasarkan perhitungan nilai pretest yang dilakukan diperoleh kesimpulan bahwa kelas III SDN SDN Sidokerto 03 Pati berdistribusi normal karena nilai L0< Ltabel yaitu 0,091 $<0,161$ dengan $n=30$ dan taraf nyata $\alpha=0,05$. Pada tahap akhir berikutnya dilakukan kembali uji normalitas dengan menggunakan nilai posttest. Berdasarkan perhitungan diperoleh $L 0=0,126$ dengan $n=30$ dan taraf nyata $\alpha=0,05$, dari daftar nilai kritis $L$ didapat Ltabel $=0,126$. Karena L0 Ltabel yaitu $0,126<0,161$, maka $\mathrm{HO}$ diterima sehingga dapat disimpulkan bahwa sampel berasal dari populasi berdistribusi normal.

Berdasarkan uji t satu pihak yaitu dengan membandingkan hasil belajar pretest dan posttest, diperoleh thitung 6,48 . Kemudian dibandingkan dengan harga ttabel pada $\mathrm{db}=29$ dan taraf $\alpha=0,05$ adalah 2,045. Kriteria pengujian hipotesis adalah $\mathrm{HO}$ diterima apabila thitung < ttabel. Pada hasil perhitungan diperoleh thitung < ttabel sehingga Ho ditolak dan $\mathrm{Ha}$ diterima. Artinya rataan nilai sebelum dan sesudah diberikan perlakuan berbeda

Berdasarkan hasil penelitian menunjukkan bahwa Keefektifan Model Examples Non Examples Terhadap Hasil Belajar Materi Pengukuran Siswa Kelas III SDN Sidokerto 03 Pati. Dengan hasil belajar meningkat dibandingkan pembelajaran yang tidak menggunakan Model Examples Non Examples. Hasil nilai pretest siswa sebelum diberi pembelajaran dengan menggunakan Model Examples Non Examples mendapatkan nilai rata - rata sebesar 57,17 terdapat 9 siswa yang telah mencapai KKM dan 21 siswa yang belum mencapai KKM. Sedangkan hasil nilai posttest siswa setelah diberi pembelajaran dengan menggunakan model mendapatkan nilai rata - rata sebesar 79,83 terdapat 25 siswa yang telah mencapai KKM dan 5 siswa yang belum mencapai KKM.

Dari pembahasan di atas dapat disimpulkan bahwa pembelajaran dengan menggunakan Model Examples Non Examples lebih baik dari pada sebelum menggunakan media,model, ataupun metode tersebut, karena rata - rata nilai tes akhir siswa kelas III yang diberi pembelajaran dengan menggunakan model pembelajaran Model Examples Non Examples lebih tinggi dibandingkan sebelum diberi pembelajaran dengan menggunakan media, model, ataupun medote yang sebelumnya. Dengan demikian terdapat Keefektifan Model Examples Non Examples Terhadap Hasil Belajar Materi Pengukuran Siswa Kelas III SDN Sidokerto 03 Pati dapat dikatakaan efektif untuk siswa kelas III SDN Sidokerto 03 Pati pada mata pelajaran matematika materi alat ukur. 


\section{Simpulan dan Saran}

Berdasarkan hasil penelitian yang telah dilakukan dapat disimpulkan ada Keefektifan Model Examples Non Examples Terhadap Hasil Belajar Materi Pengukuran Siswa Kelas III SDN Sidokerto 03 Pati.

Dibuktikan dengan perolehan - perolehan nilai rata - rata hasil pretest siswa yang sebesar 57,17 dan rata-rata nilai hasil posttetst dengan menggunakan Model Examples Non Examples sebesar 79,83. Dari tabel uji t diperoleh, untuk, maka diperoleh dan . Karena yaitu maka ditolak. Dengan demikian terdapat Keefektifan Model Examples Non Examples Terhadap Hasil Belajar Materi Pengukuran Siswa Kelas III SDN Sidokerto 03 Pati.

\section{Daftar Pustaka}

Arikunto, Suharsimi. 2010. Prosedur Penelitian Suatu Pendekatan Praktik. Jakarta:Rineka Cipta.

Damiati (2013) "Pengaruh Model Pembelajaran Example non Example terhadap Hasil Belajar Matematika Siswa Pada Materi Bangun Datar Kelas VII MTSN KarangRejo Tulungagung" Skripsi: Sekolah Tinggi Agama Islam Negeri Tulungagung Program Studi Tadri Matematika.

Fatturosidah, Ani. 2012. Pengaruh Metode Example Non Example Berbantu Media Audio Visual Terhadap Hasil Belajar Sub Tema Kepahlawanan Kelas IV SDN Batursari 6". Skripsi

Hamdani. 2011. Strategi Belajar Mengajar. Bandung: Pustaka Setia.

Hanafiah \& Suhana. 2009. Konsep Strategi Pembelajaran. Bandung: Refika Aditama

Huda, M. 2013. Model-model Pengajaran dan Pembelajaaran. Pustaka Pelajar Offset. Yogyakarta.

Nurul, Astuti Yensi. 2012. Penerapan Model Pembelajaran Kooperatif Tipe Example Non Example Dengan Menggunakan Alat Peraga Untuk meningkatkan Hasil Belajar Siswa Di Kelas VIII SMP Negeri 1 Argamakmur. Jurnal Exacta (Vol. X No. 1).

Rhani Novyani. 2011. "Peningkatan Keterampilan Menulis Paragraf Deskripsi dengan Model Example non Example melalui Media Video Compact Disc (VCD) Flora dan Fauna.

Sadiman, dkk. 2012. Media Pembelajaran. Jakarta: Raja Grafindo.

Susanto, Andriawan. 2017. KEEFEKTIFAN MODEL PEMBELAJARAN EXAMPLES NONEXAMPLES UNTUK MENINGKATKAN HASIL BELAJAR KOMPETENSI DASAR SISTEM INJECTOR NOZZLE DAN GLOW PLUG. Jurnal Pendidikan Teknik Mesin Vol. 17, No. 1, Juni 2017 (7-10).

Trianto. 2007. Model-model Pembelajaran Inovatif Berorientasi Kontruktivistik. Prestasi Pustaka Publisher.Jakarta.

Utami, S., Asrul, dan Yurnetti. 2015. Pengaruh Bahan Ajar Berorientasi Model Pembelajaran Model Kooperatif Examples Non-Examples Terhadap Hasil Belajar IPA Siswa Kelas VIII SMP N 16 Kerinci. Jurnal Pillar of Physics Education Universitas Negeri Padang, Volume 6 Tahun 2015. 
Wahyudi, dan Kriswandani. 2013. Pengembangan Pembelajaran Matematika SD. Salatiga: Widya Sari Press

Yensy. B,Nurul Astuty. 2012. PENERAPAN MODEL PEMBELAJARAN KOOPERATIF TIPE EXAMPLES NON EXAMPLES DENGAN MENGGUNAKAN ALAT PERAGA UNTUK MENINGKATKAN HASIL BELAJAR SISWA DI KELAS VIII SMP N 1 ARGAMAKMUR. Jurnal Exacta, Vol. X No. 1. 